\title{
REVISI TAKSONOMI PEMBELAJARAN BENYAMIN S. BLOOM
}

\author{
I Putu Ayub Darmawan \\ Mahasiswa Program Studi Magister Manajemen Pendidikan \\ FKIP Universitas Kristen Satya Wacana \\ Edy Sujoko \\ Mahasiswa Program Studi Magister Manajemen Pendidikan \\ FKIP Universitas Kristen Satya Wacana
}

\begin{abstract}
ABSTRAK
Fokus utama dalam tulisan ini adalah untuk mendeskripsikan perubahan Taksonomi Bloom diantaranya perubahan nama dalam taksonomi yang mengambil bentuk menjadi kata kerja, perubahan urutan taksonomi dimana evaluasi dalam taksonomi lama terdapat pada urutan akhir berubah menjadi urutan kelima dan sintesis dalam taksonomi lama diganti menjadi mencipta, dan perubahan sub kategori. Tulisan ini juga menguraikan tentang hal-hal penting dalam revisi taksonomi seperti pengetahuan metakognisi dan tabel taksonomi. Serta manfaat taksonomi revisi dalam belajar bermakna. Taksonomi Bloom menjadi kasifikasi pernyataan-pernyataan yang digunakan untuk memprediksi kemampuan peserta didik dalam belajar sebagai hasil dari kegiatan pembelajaran. Pengaruh taksonomi Bloom lama telah dirasakan sampai saat ini dan memberi manfaat yang sangat berharga. Revisi taksonomi Bloom meliputi perubahan nama dalam taksonomi dari kata benda menjadi kata kerja, urutan taksonomi yang melingkupi perubahan tata letak evaluasi, perubahan sintesa menjadi mencipta.
\end{abstract}

Kata Kunci: taksonomi Bloom, taksonomi revisi, tabel taksonomi, pengetahuan metakognisi, belajar bermakna.

\section{PENDAHULUAN}

Secara etimologi kata taksonomi berasal dari bahasa Yunani yaitu taxis dan nomos. Taxis berarti 'pengaturan atau divisi' dan nomos berarti hukum (Enghoff, 2009:442). Jadi secara etimologi taksonomi dapat diartikan sebagai hukum yang mengatur sesuatu. Taksonomi dapat diartikan sebagai pengelompokan suatu hal berdasarkan hierarki (tingkatan) tertentu. Di mana taksonomi yang lebih tinggi bersifat lebih umum dan taksonomi yang lebih rendah bersifat lebih spesifik (http://id.wikipedia.org/ wiki/Taksonomi). Taksonomi dapat digambarkan seperti sebuah hubungan antara ayah dan anak yang berada dalam satu struktur hirarki yang terhubung antara satu dengan yang lain. Taksonomi adalah sebuah kerangka untuk mengklasifikasikan pernyataan-pernyataan yang digunakan untuk memprediksi kemampuan peserta didik dalam belajar sebagai hasil dari kegiatan pembelajaran.

Taksonomi Bloom telah mempengaruhi pendidikan baik secara langsung maupun tidak langsung dalam pengembangan kurikulum, desain pembelajaran dan pendidikan guru. Hal ini terbukti, Handbook atau Taksonomi Bloom beserta dengan contoh-contoh yang diketengahkan di dalamnya, kerap kali dikutip dalam banyak sekali buku teks tentang pengukuran (measurement), kurikulum, dan pendidikan guru (Anderson \& Krathwohl, 
2010:vii-viii). Taksonomi Bloom memiliki tiga ranah diantaranya 1) ranah kognitif, yang mencakup ingatan atau pengenalan terhadap faktafakta tertentu, pola-pola prosedural, dan konsepkonsep yang memungkinkan berkembangnya kemampuan dan skill intelektual (Huda, 2013:169); 2) ranah afektif, ranah yang berkaitan perkembangan perasaan, sikap, nilai dan emosi; 3) ranah psikomotor, ranah yang berkaitan dengan kegiatan-kegiatan manipulatif atau keterampilan motorik (Degeng, 2013:202). Pengembangan keterampilan ini memerlukan latihan dan diukur dalam hal kecepatan, ketepatan, jarak, prosedur, atau teknik dalam pelaksanaan. Taksonomi Bloom pada 1956 dituangkan dalam sebuah buku The Taxonomy of Educational Objectives, The Classification of Educational Goal, Handbook I: Cognitive Domain. Buku yang menjelaskan tentang sistem klasifikasi pendidikan tersebut disebut sebagai Handbook. Handbook tersebut kemudian direvisi dengan dua alasan yaitu: 1) terdapat kebutuhan untuk mengarahkan kembali fokus para pendidik pada Handbook, bukan sekadar sebagai dokumen sejarah, melainkan juga sebagai karya yang dalam banyak hal telah "mendahului" jamannya (Rohwer dan Sloane, 1994 dlm. Anderson dan Krathwohl, 2010:viii); 2) adanya kebutuhan untuk memadukan pengetahuan-pengetahuan dan pemikiran-pemikiran baru dalam sebuah kerangka kategorisasi tujuan pendidikan. Kemajuan dalam khazanah ilmu ini mendukung keharusan untuk merevisi Handbook (Anderson dan Krathwohl, 2010:viii).

Dari ketiga ranah tersebut di atas, tulisan ini akan membahas ranah kognitif yang terdiri dari enam kategori utama, khususnya membahas tentang 1) perubahan taksonomi diantaranya perubahan nama dalam taksonomi, urutan taksonomi, dan perubahan sub kategori; 2) manfaat revisi diantaranya manfaat pengetahuan metakognisi, manfaat tabel taksonomi, dan manfaat belajar bermakna.

Tulisan ini diharapkan akan menambah pengetahuan tentang: 1) aspek-aspek apa yang mengalami perubahan dalam taksonomi Bloom ini; 2) manfaat yang akan diperoleh dari revisi taksonomi Bloom.

\section{PERUBAHAN TAKSONOMI}

\section{Kategori-Kategori Dalam Taksonomi Lama}

Taksonomi Bloom ranah kognitif sebelum direvisi mencakup tentang enam hal. Penjelasan untuk keenam hal tersebut diambil dari uraian Degeng (2013:202-203) dan Turmuzi (2013). Enam klasifikasi yang tercakup dalam ranah kognitif adalah a) Pengetahuan (knowledge) yang menekankan pada mengingat, apakah dengan mengungkapkan atau mengenal kembali suatu yang telah pernah dipelajari dan disimpan dalam ingatan. Bagian ini berisikan kemampuan untuk mengenali dan mengingat peristilahan, definisi, fakta-fakta, gagasan, pola, urutan, metodologi, prinsip dasar, dan sebagainya; b) Pemahaman (comprehension) yang menekankan pada pengubahan informasi ke bentuk yang lebih mudah dipahami. Contoh untuk klasifikasi ini adalah peserta didik dituntut bisa memahami apa yang diuraikan dalam gambar piramida penduduk, tabel atau diagram pertumbuhan penduduk, dan sebagainya; c) Aplikasi (application) yang hasil belajarnya menggunakan abstraksi pada situasi tertentu dan konkret. Tekanannya adalah untuk memecahkan suatu masalah. Di tingkat ini, seseorang (peserta didik) memiliki kemampuan untuk menerapkan gagasan, prosedur, metode, rumus, teori, dan sebagainya di dalam kondisi pembelajaran; d) Analisis (analysis) dimana hasil belajar yang diperoleh pada klasifikasi ini adalah memilah informasi ke dalam satuan-satuan bagian yang lebih rinci sehingga dapat dikenali fungsinya, kaitannya dengan bagian yang lebih besar, serta organisasi keseluruhan bagian. Peserta didik diharapkan akan mampu menganalisa informasi yang diterimanya dan membagi-bagi informasi tersebut ke dalam bagian yang lebih kecil untuk mengenali pola informasi tersebut atau korelasinya. Contoh untuk level ini adalah peserta didik diarahkan untuk mampu memilah-milah penyebab ledakan penduduk di beberapa daerah di Indonesia, membanding-bandingkan faktor penyebab ledakan penduduk di beberapa daerah di Indonesia, dan menggolongkan setiap penyebab berdasarkan karakteristiknya, atau menggolongkan faktor 
yang menonjol dalam ledakan penduduk tersebut; e) Sintesis (synthesis), hasil belajar dari klasifikasi sintesis adalah penyatuan bagian-bagian untuk membentuk suatu kesatuan yang baru dan unik. Peserta didik di tingkat sintesa akan mampu menjelaskan struktur atau pola dari sebuah skenario yang sebelumnya tidak terlihat, dan mampu mengenali data atau informasi yang harus didapat untuk menghasilkan solusi yang dibutuhkan; f) Evaluasi (evaluation), hasil yang diperoleh adalah pertimbangan-pertimbangan tentang nilai dari sesuatu untuk tujuan tertentu. Dalam klasifikasi ini peserta didik diperkenalkan tentang kemampuan untuk memberikan penilaian terhadap solusi, gagasan, metodologi, dan sebagainya dengan menggunakan kriteria yang cocok atau standar yang ada untuk memastikan nilai efektivitas atau manfaatnya.

\section{Nama Dalam Taksonomi}

Nama-nama dalam taksonomi Bloom mengalami perubahan dari nama dengan kata benda ke nama dengan kata kerja. Perubahan tersebut dapat dilihat dalam bagan 1 .

Dalam taksonomi revisi Aplikasi, Analisis, dan Evaluasi dipertahankan, tetapi dalam bentuk kata kerja sebagai Menerapkan,
Menganalisis, dan Mengevaluasi. Sintesis berubah tempat dengan Evaluasi dan berganti nama Mencipta (Krathwohl, 2002:214). Komponen kata kerja dari Pengetahuan berubah menjadi kategori mengingat, yang menggantikan klasifikasi pengetahuan aslinya dalam enam kategori pokok, yang sekarang menggunakan kata kerja. Bentuk kata kerja ini mendeskripsikan tindakan yang tersirat dalam kategori pengetahuan aslinya; tindakan pertama yang dilakukan siswa dalam belajar pengetahuan adalah mengingatnya (Anderson \& Krathwohl, 2010:400).

\section{Urutan Taksonomi}

Dalam taksonomi Bloom revisi urutan taksonomi yang mengalami perubahan adalah letak evaluasi dan sintesa serta penggantian nama komprehensi menjadi memahami dan sintesa menjadi mencipta (perhatikan Bagan 1). Perubahan urutan kategori-kategori dalam taksonomi Bloom didasari oleh kerangka berpikir revisi adalah hierarki dalam pengertian bahwa enam kategori pokok pada dimensi proses kognitif disusun secara berurutan dari tingkat kompleksitas yang rendah ke tinggi. Sementara itu, kategori-kategori pada skema aslinya diklaim sebagai sebuah hierarki

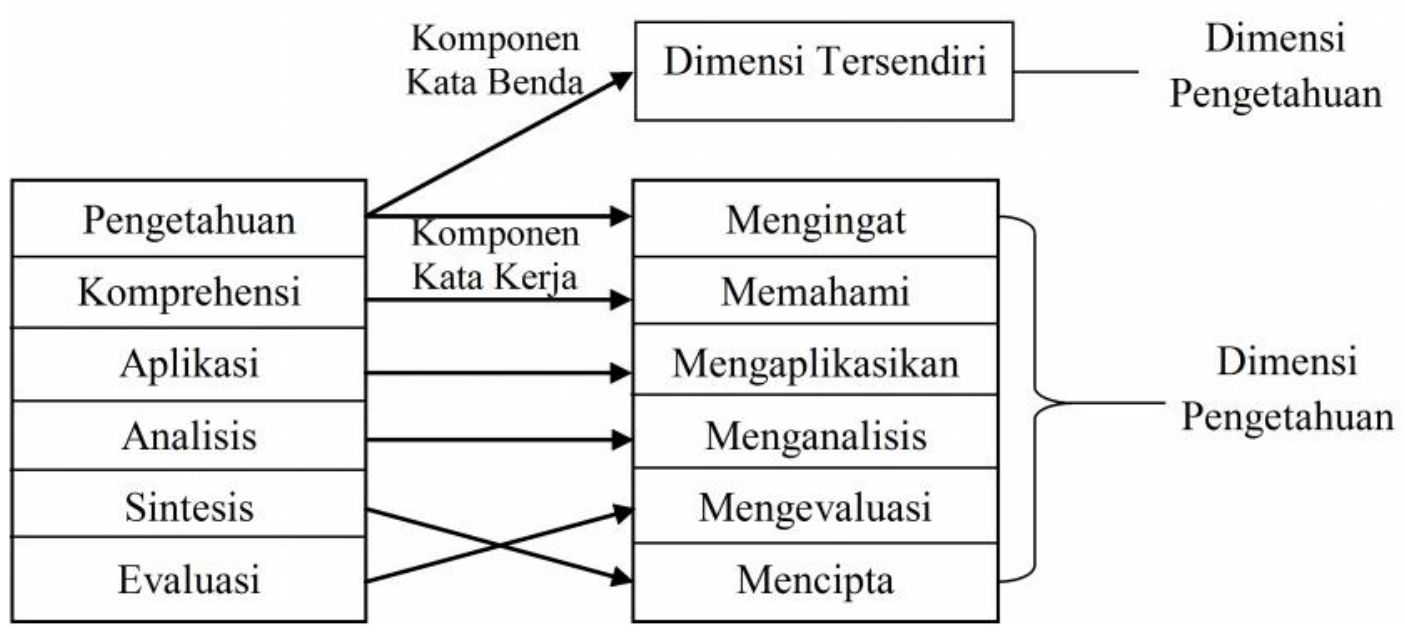

Bagan 1. Ringkasan Perubahan Struktural dari Kerangka Pikir Asli ke Revisinya (Anderson \& Krathwohl, 2010:403). 
komulatif. Ini berarti bahwa penguasaan kategori yang lebih kompleks dalam skema aslinya mensyaratkan penguasaan semua kategori di bawahnya yang kurang kompleks (Anderson \& Krathwohl, 2010:401).

Dalam taksonomi revisi Komprehensi/ Pemahaman berganti nama menjadi memahami karena salah satu kriteria untuk memilih kategori tabel adalah penggunaan istilah yang digunakan guru dalam berbicara tentang pekerjaan mereka. Karena yang dipahami adalah istilah yang umum digunakan dalam tujuan, kurangnya inklusi sering menjadi kritik dari Taksonomi lama. Pemahaman menjadi memahami terjadi karena memahami merupakan salah satu proses kognitif yang berpijak pada kemampuan transfer. Anderson dan Krathwohl (2010:105-114) menjelaskan siswa dikatakan memahami jika mereka dapat mengkonstruksi makna dari pesan-pesan pembelajaran, baik yang bersifat lisan, tulisan ataupun grafis, yang disampaikan melalui pengajaran, buku, atau layar komputer. Proses-proses kognitif dalam kategori memahami meliputi: 1) proses kognitif menafsirkan yang terjadi ketika siswa dapat mengubah informasi dari satu bentuk ke bentuk lain; 2) proses kognitif mencontohkan yang terjadi ketika siswa memberikan contoh tentang konsep atau prinsip umum; 3) proses kognitif mengklasifikasikan terjadi ketika siswa mengetahui bahwa sesuatu (misalnya, suatu contoh) termasuk dalam kategori tertentu (misalnya, konsep atau prinsip); 4) proses kognitif merangkum yang terjadi ketika siswa mengemukakan satu kalimat yang merepresentasikan informasi yang diterima atau mengabstraksi sebuah tema; 5) proses kognitif menyimpulkan menyertakan proses menemukan pola dalam sejumlah contoh; 6) proses kognitif membandingkan melibatkan proses mendeteksi persamaan dan perbedaan antara dua atau lebih objek, peristiwa, ide, masalah, atau situasi, seperti menentukan bagaimana suatu peristiwa terkenal menyerupai peristiwa yang kurang terkenal; 7) proses kognitif menjelaskan yang berlangsung ketika siswa dapat membuat dan menggunakan model sebab akibat dalam sebuah sistem.
Dalam taksonomi revisi kategori sintesa diubah menjadi mencipta. Kategori mencipta melibatkan proses penyusunan elemen-elemen jadi sebuah keseluruhan yang koheren atau fungsional. Tujuan-tujuan yang diklasifikasikan dalam Mencipta meminta siswa membuat produk baru dengan mereorganisasi sejumlah elemen atau bagian jadi satu pola atau struktur yang tidak pernah ada sebelumnya. Dalam mencipta siswa mengumpulkan elemen-elemen dari banyak sumber dan menggabungkan mereka jadi sebuah struktur atau pola baru yang bertalian dengan pengetahuan siswa sebelumnya. Mencipta berisikan tiga proses kognitif: 1) merumuskan yang melibatkan proses menggambarkan masalah dan membuat pilihan atau hipotesis yang memenuhi kriteria-kriteria tertentu; 2) merencanakan yang melibatkan proses merencanakan metode penyelesaian masalah yang sesuai dengan kriteriakriteria masalahnya, yakni membuat rencana untuk menyelesaikan masalah; 3) memproduksi melibatkan proses melaksanakan rencana untuk menyelesaikan masalah yang memenuhi spesifikasi-spesifikasi tertentu (Anderson \& Krathwohl, 2010:128-132).

\section{Perubahan Sub Kategori}

Dalam taksonomi lama setiap kategori memiliki sub-kategori; Pengetahuan dan Komprehensi mempunyai banyak subkategori. Kategori dan sub-kategori ini berada dalam sebuah kontinum, dari tingkat sederhana ke kompleks dan dari tingkat konkret ke abstrak. Hubungan antarkategori dalam kontinum ini bersifat hierarki komulatif (Anderson \& Krathwohl, 2010:395).

Dalam Taksonomi Bloom revisi perubahan subkategori sangat menonjol nampak terjadi pada kategori memahami dan menganalisa (lihat tabel 1). Karena terjadi perubahan nama dalam taksonomi maka sub-kategori dari masing-masing kategori mengalami perubahan juga. Semua subkategori lama digantikan dengan sub-kategori yang baru dan disebut sebagai proses kognitif. Perubahan sub kategori pada kategori memahami membuat cara penggunaanya menjadi lebih luas karena sub-sub kategori yang menunjukkan batas- 
batas kategori memahami dapat ditukarposisikan dengan mengaplikasikan (Anderson \& Krathwohl, 2010:401). Dalam taksonomi lama kerangka pikirnya menekankan pada keenam kategorinya. Sementara dalam taksonomi revisi, devinisi kategori-kategori pokok menjadi sangat jelas dalam pemaparan dan ilustrasi sub-kategorinya yang panjang lebar (yakni, sub-subjenis pengetahuan dan prosesproses kognitif yang spesifik) dan penggunaan sub-subkategori itu dalam menganalisis sketsa pembelajaran-vinyetnya (Anderson \& Krathwohl, 2010:397-398).

Taksonomi revisi melakukan perubahan dalam sub-sub-kategori proses kognitif yang berbentuk kata benda diubah atau diganti dengan menggunakan kata kerja. Alasan menggunakan kata kerja karena jika sub-subkategori menggunakan kata kerja tentu akan lebih bermanfaat bagi guru untuk merumuskan tujuan dan, dalam proses pembelajaran, untuk menstrukturkan dan mengkategorikan tujuan, aktivitas pembelajaran, dan tugas asesmennya. Lebih jelas Anderson dan Krathwohl (2010:399) menjelaskan dua alasan menggunakan kata kerja. Alasannya adalah (1) kata kerja merepresentasikan proses-proses kognitif yang dijelaskan dalam teori dan hasil penelitian kognitif, dan (2) kata kerja merupakan jenisjenis proses yang lazim dijumpai dalam rumusan tujuan dan rencana unit pengajaran guru.

\section{HAL-HAL TERPENTING DALAM REVISI TAKSONOMI}

\section{Pengetahuan Metakognisi}

Pengetahuan Metakognitif adalah pengetahuan tentang kognisi secara umum dan kesadaran akan, serta pengetahuan tentang, kognisi diri sendiri (Anderson \& Krathwohl, 2010:82). Pintrich (2002:220) mengungkapkan metacognitive knowledge involves knowledge about cognition in general, as well as awareness of and knowledge about one's own cognition. Jadi
Pengetahuan metakognitif melibatkan pengetahuan tentang kognisi secara umum, serta kesadaran dan pengetahuan tentang kognisi sendiri. Pengetahuan metakognitif meliputi knowledge of general strategies that might be used for differeni tasks, knowledge of the conditions under which these strategies might be used, knowledge of the extent to which the strategies are effective, and knowledge of self (dalam Pintrich, 2002:220).

Metakognisi adalah suatu istilah yang berkaitan dengan apa yang diketahui seseorang tentang individu yang belajar dan bagaimana dia mengontrol serta menyesuaikan perilakunya. Metakognisi juga merupakan bentuk kemampuan untuk melihat pada diri sendiri sehingga apa yang dia lakukan dapat terkontrol secara optimal (Tim Pengembang Ilmu Pendidikan UPI, 2007:167). Metakognisi bermanfaat untuk melihat pada diri sendiri sejauh mana dan seperti apa individu telah belajar. Dengan pengetahuan tersebut ia akan dapat mengontrol dan menyesuaikan perlakunya.

Metakognisi secara umum dibagi menjadi dua bidang yang saling berkaitan satu sama lain. Pertama, adalah pengetahuan metakognisi yang merupakan kesadaran tetang berpikirnya, dimana siswa mengerti apa yang ia ketahui, yang tidak ia ketahui, dan yang ingin diketahui. Siswa dapat mengajukan pertanyaan seperti, "apa yang saya ketahui? Apa yang tidak saya ketahui? Apa yang perlu saya ketahui?. Peran guru dalam hal ini adalah menolong untuk melakukan refleksi tentang apa yang mereka ketahui dan apa yang ingin mereka ketahui ketika mereka hendak mempelajari topik-topik baru. Kedua, pengaturan metakognitif yang berkaitan dengan kecakapan untuk mengelola proses berpikirnya sendiri.

Flavell (1979, dlm. Anderson \& Krathwohl, 2010:83-85) menyatakan bahwa metakognisi mencakup pengetahuan tentang strategi, tugastugas kognitif, dan variabel-variabel person. 
Tabel 1. Perbandingan Taksonomi Asli dengan Taksonomi Revisi (Krathwohl, 2002:213, 215)

\begin{tabular}{|c|c|}
\hline Struktur Taksonomi Asli & Struktur Taksonomi Revisi \\
\hline \multirow[t]{2}{*}{$\begin{array}{l}\text { 1.0 Pengetahuan } \\
1.10 \text { Pengetahuan tentang hal-hal khusus }\end{array}$} & \multirow{13}{*}{$\begin{array}{l}\text { 1.0 Mengingat - Memanggil pengetahuan yang } \\
\text { relevan darimemori jangka panjang. } \\
1.1 \text { Mengenali } \\
\text { 1.2 Mengingat kembali }\end{array}$} \\
\hline & \\
\hline $\begin{array}{c}1.11 \text { Pengetahuan tentang istilah-istilah/ } \\
\text { terminologi }\end{array}$ & \\
\hline $\begin{array}{l}1.12 \text { Pengetahuan tentang fakta-fakta } \\
\text { tertentu }\end{array}$ & \\
\hline $\begin{array}{l}\text { 1.20 Pengetahuan tentang cara dan sarana untuk } \\
\text { menangani hal hal khusus }\end{array}$ & \\
\hline $\begin{array}{l}1.21 \text { Pengetahuan tentang kebiasaan- } \\
\text { kebiasaan }\end{array}$ & \\
\hline $\begin{array}{l}\text { 1.22 Pengetahuan tentang kecen-derungan- } \\
\text { kecenderungan dan urut-urutan } \\
\text { kegiatan }\end{array}$ & \\
\hline $\begin{array}{l}\text { 1.23 Pengetahuan tentang klasifikasi- } \\
\text { klasifikasi dan kategori-kategori }\end{array}$ & \\
\hline 1.24 Pengetahuan tentang kriteria & \\
\hline 1.25 Pengetahuan tentang metodo-logi & \\
\hline $\begin{array}{l}\text { 1.30 Pengetahuan tentang hal-hal umum/universal } \\
\text { dan abstraksi-abstraksi dalam bidang tertentu }\end{array}$ & \\
\hline $\begin{array}{c}1.31 \text { Pengetahuan tentang prinsip-prinsip } \\
\text { dan generalisasi-generalisasi }\end{array}$ & \\
\hline $\begin{array}{l}\text { 1.32 Pengetahuan tentang teori -teorindan } \\
\text { struktur-struktur }\end{array}$ & \\
\hline $\begin{array}{l}\text { 2.1 Terjemahan } \\
\text { 2.2 Penafsiran }\end{array}$ & $\begin{array}{l}\text { 2.0 Memahami - Membangun makna dari pesan } \\
\text { pembelajaran, termasuk pesan komunikasi lisan, } \\
\text { tertulis, dan grafis. }\end{array}$ \\
\hline \multirow[t]{7}{*}{ 2.3 Peramalan/Ekstrapolasi } & 2.1 Menafsirkan \\
\hline & 2.2 Mencontohkan \\
\hline & 2.3 Mengklasifikasikan \\
\hline & 2.4 Merangkum \\
\hline & 2.5 Menyimpulkan \\
\hline & 2.6 Membandingkan \\
\hline & 2.7 Menjelaskan \\
\hline 3.0 Aplikasi & $\begin{array}{l}\text { 3.0 Menerapkan - Melaksanakan atau menggunakan } \\
\text { prosedur dalam situasi tertentu. } \\
\text { 3.1 Mengeksekusi/melaksanakan } \\
\text { 3.2 Mengimplementasikan }\end{array}$ \\
\hline \multirow{8}{*}{$\begin{array}{l}\text { 4.0 Analisis } \\
\text { 4.1 Analisis unsur-unsur/bagian-bagian } \\
\text { 4.2 Analisis saling hubungan } \\
\text { 4.3 Analisis prinsip-prinsip terorgani-sasi }\end{array}$} & 4.0 Menganalisa - Memilahmateri menjadi bagian- \\
\hline & bagianpenyusunnyadan mengenali saling \\
\hline & hubungan antar bagian, dan hubungan antara \\
\hline & bagian-bagian dengan struktur atau tujuansecara \\
\hline & keseluruhan. \\
\hline & 4.1 Membedakan \\
\hline & 4.2 Mengorganisasikan \\
\hline & 4.3 Mengatribusi \\
\hline 5.0 Sintesis & 5.0 Mengevaluasi - Membuat penilaian berdasarkan \\
\hline 5.1 Produksi komunikasi yang khas & kriteria dan standar. \\
\hline \multirow{2}{*}{$\begin{array}{l}\text { 5.2 Produksi rencana, atau seperangkat pelaksanaan } \\
\text { kegiatan }\end{array}$} & 5.1 Memeriksa \\
\hline & 5.2 Mengkritisi \\
\hline \multicolumn{2}{|l|}{ 5.3 Penerjemahan seperangkat hubung-an abstrak } \\
\hline \multirow{6}{*}{$\begin{array}{l}\text { 6.0 Evaluasi } \\
\text { 6.1 Evaluasi dengan bukti internal } \\
6.2 \text { Evaluasi dengan kriteria eksternal }\end{array}$} & 6.0 Menciptakan - Memadukan unsur-unsur /bagian- \\
\hline & bagian ke dalam sesuatu yang baru dan utuh atau \\
\hline & untuk membuat sesuatu produk yang orisinil. \\
\hline & 6.1 Merumuskan/membangun \\
\hline & 6.2 Merencanakan \\
\hline & 6.3 Memproduksi \\
\hline
\end{tabular}


Pengetahuan Strategis adalah pengetahuan perihal strategi-strategi belajar dan berpikir tentang pemecahan masalah. Subjenis pengetahuan ini mencakup pengetahuan tentang berbagai strategi yang siswa dapat gunakan untuk menghafal materi pelajaran, mencari makna teks, atau memahami apa yang mereka dengar dari pelajaran di kelas atau apa yang mereka baca dalam buku atau bahan ajar lain. Beberapa contoh pengetahuan strategis adalah

- Pengetahuan bahwa mengulang-ulang informasi merupakan salah satu cara menanamkan informasi.

- Pengetahuan perihal beraneka strategi mnemonik untuk menghafal (misalnya, memakai akronim seperti mejikuhibiniu (merah jingga kuning hijau biru nila ungu) untuk warna-warna pelangi).

- Pengetahuan tentang berbagai strategi elaborasi seperti memparaprase dan merangkum.

- Pengetahuan tentang beragam strategi pengorganisasian seperti menulis garis besar dan menggambar diagram.

Selain pengetahuan strategis menurut Flavell (1979, dalam Anderson \& Krathwohl, 2010:85-87) individu-individu mengakumulasi pengetahuan dengan tugas-tugas kognitif. Pengetahuan tugas-tugas kognitif meliputi pengetahuan kontekstual dan pengetahuan kondisional. Pengetahuan kondisional adalah pengetahuan tentang situasi yang di dalamnya siswa dapat menggunakan Pengetahuan Metakognitif. Salah satu hal penting yang perlu diperhatikan dalam mempelajari strategi adalah pengetahuan kondisional tentang kapan dan mengapa harus menggunakan strategi tertentu. Untuk menerapkan strategi yang tepat, aspek penting yang perlu diperhatikan dalam pengetahuan kondisional adalah norma-norma lokal situasional, sosial secara umum, konvensional, dan kultural. Contoh pengetahuan tentang tugas-tugas kognitif, yang meliputi pengetahuan pengetahuan kontekstual dan kondisional adalah:
- Pengetahuan bahwa tugas mengingat kembali (misalnya, soal jawaban singkat) - berbeda dengan tugas mengenali (misalnya, soal pilihan ganda) - pada umumnya lebih banyak menuntut kerja sistem memori.

- Pengetahuan bahwa buku babon lebih sukar dipahami ketimbang buku teks atau buku populer.

- Pengetahuan bahwa tugas sederhana untuk menghafal sederhana (misalnya, mengingat sebuah nomor telepon) hanya membutuhkan strategi petualangan.

- Pengetahuan bahwa strategi elaborasi seperti seperti merangkum dan memparafrasakan dapat membuahkan pemahaman yang mendalam.

Flavell (1979, dalam Anderson \& Krathwohl, 2010:88-90) mengemukakan selain pengetahuan strategis dan pengetahuan dengan tugas-tugas kognitif, juga pengetahuan-diri sebagai komponen penting dari metakognisi. Menurutnya, pengetahuan-diri mencakup pengetahuan tentang kekuatan dan kelemahan diri sendiri dalam kaitannya dengan kognisi dan belajar. Misalnya, siswa yang tahu bahwa diri mereka lebih mampu mengerjakan tes pilihan ganda ketimbang tes esai berarti mempunyai pengetahuan-diri tentang keterampilan mereka mengerjakan tes. Contoh pengetahuan diri adalah:

- Pengetahuan bahwa dirinya mempunyai pengetahuan yang mendalam pada sebagian bidang, tetapi tidak pada sebagian bidang lainnya.

- Pengetahuan bahwa dirinya cenderung mengandalkan satu "alat kognitif" (strategi) dalam situasi tertentu.

- Pengetahuan yang akurat dan tidak palsu (misalnya, kepercayaan diri yang berlebihan) tentang kemampuan sendiri untuk melakukan tugas tertentu. 
- Pengetahuan tentang tujuan-tujuan pribadi dalam melakukan suatu tugas.

Strategi-strategi metakognisi akan menolong untuk menjadi lebih efisien dan lebih berkekuatan dalam belajar karena strategi-strategi tersebut menolong untuk menemukan informasi, menilai kapan perlu tambahan sumberdaya, dan mengerti kapan harus menerapkan pendekatan yang berbeda terhadap suatu masalah. Ketika anak-anak mulai menguasai strategi-strategi ini, kemudian belajar kapan, bagaimana dan mengapa menggunakannya maka mereka mampu belajar secara lebih bertujuan dan lebih efektif (Brown, 1977 dalam Darling-Hammond, 2003). Metakognisi menjadikan belajar lebih efisien dan lebih berkekuatan.

\section{Tabel Taksonomi}

Dalam Taksonomi yang telah direvisi, hasil belajar apapun akan diwakili dalam dua dimensi yang segera menyajikan kemungkinan membangun sebuah tabel dua dimensi, yang disebut Tabel Taksonomi. Dimensi Pengetahuan pada sumbu vertikal dari tabel, sedangkan proses kognitif pada sumbu horisontal (Krathwohl, 2002:215).

Tabel Taksonomi sebagaimana nampak pada tabel 2, bermanfaat untuk membantu para guru dan pendidik lainnya setidaknya dengan tiga cara. Pertama, Tabel Taksonomi dapat membantu para guru lebih memahami tujuan-tujuan pembelajaran mereka (tujuan yang mereka buat sendiri dengan tujuan-tujuan yang telah disediakan oleh pihak lain); yakni, Tabel Taksonomi membantu para pendidik penjawab pertanyaan apa yang disebut dengan "pertanyaan tentang pembelajaran". Kedua, dengan pemahaman yang lebih utuh perihal tujuan-tujuan pembelajaran mereka, guruguru dapat menggunakan Tabel Taksonomi untuk membuat keputusan-keputusan yang lebih bagus mengenai bagaimana mengajar dan mengases siswa dengan kerangka tujuan-tujuan pembelajaran itu; yakni, Tabel Taksonomi membantu para pendidik menjawab "pertanyaan tentang pembelajaran" dan "pertanyaan tentang asesmen". Ketiga, Tabel Taksonomi dapat membantu mereka menentukan seberapa sesuai antara tujuan, asesmen, dan pembelajarannya dengan cara yang tepat; yakni, Tabel Taksonomi membantu para pendidik menjawab "pertanyaan tentang kesesuaian semua komponen" (Anderson \& Krathwohl, 2010:143).

Krathwohl (2002:217) menjelaskan bahwa The Taxonomy Table can also be used to classify the instructional and learning activities used to achieve the objectives, as well as the assessments employed to determine how well the objectives were mastered by the students. Tabel Taksonomi memberi manfaat bagi guru untuk mengklasifikasikan kegiatan pembelajaran dan pembelajaran yang digunakan untuk mencapai tujuan, serta menolong untuk membuat penilaian digunakan untuk menentukan seberapa baik tujuan yang dikuasai oleh siswa.

Tabel 2. Tabel Taksonomi (Anderson \& Krathwohl, 2010:40)

\begin{tabular}{l|l|l|l|l|l|l}
\hline \multirow{2}{*}{\begin{tabular}{l} 
Dimensi \\
\cline { 2 - 6 }
\end{tabular}} & \multicolumn{5}{|c}{ Dimensi Proses Kognitif } \\
\hline $\begin{array}{l}\text { A. Pengetahuan } \\
\text { Faktual }\end{array}$ & 1. Mengingat & 2. Memahami & 3. Menerapkan & 4. Menganalisa & 5. Mengevaluasi & 6. Mencipta \\
\hline $\begin{array}{l}\text { B. Pengetahuan } \\
\text { Konseptual }\end{array}$ & & & & & & \\
\hline $\begin{array}{l}\text { C. Pengetahuan } \\
\text { Prosedural }\end{array}$ & & & & & & \\
\hline $\begin{array}{l}\text { D. Pengetahuan } \\
\text { Metakognitif }\end{array}$ & & & & & & \\
\hline
\end{tabular}




\section{TAKSONOMI REVISI DAN BELAJAR BERMAKNA}

Sebelum mempelajari tentang belajar bermakna terlebih dahulu melihat tiga skenario belajar. Anderson dan Krathwohl (2010:95) membagi ke dalam tiga skenario belajar. Skenario pertama adalah tidak ada aktivitas belajar (yakni tiada aktivitas belajar yang diinginkan), skenario kedua ialah belajar menghafal (rote learning), dan skenario ketiga adalah belajar yang bermakna (meaningful learning). Pada bagian ini perhatian diarahkan pada bagaimana tabel taksonomi mendorong terjadinya proses belajar bermakna yang merupakan salah satu dari tiga skenario belajar.

Belajar yang bermakna menghadirkan pengetahuan dan proses kognitif yang siswa butuhkan untuk menyelesaikan masalah. Penyelesaian masalah terjadi ketika siswa menggagas cara untuk mencapai tujuan yang belum pernah dia capai, yakni mengerti bagaimana cara mengubah keadaan jadi keadaan yang diinginkan (Anderson \& Krathwohl, 2010:97). Dalam belajar bermakna proses belajar yang terjadi adalah mengkonstruksikan pengetahuan, yang di dalamnya siswa berusaha memahami pengalaman-pengalaman mereka (Anderson dan Krathwohl, 2010:98). Sehingga fokus dalam belajar bermakna adalah mengkonstruksi pengetahuan sebagai usaha memahami pengalaman-pengalaman siswa. Belajar yang bermakna mendorong pembelajaran tidak hanya sekedar menyampaikan sebuah pengetahuan faktual melainkan menjadi pembelajaran dimana guru mengajukan pertanyaanpertanyaan asessmen yang menuntut lebih dari sekedar mengingat atau mengenali pengetahuan faktual. Sebagai contoh saat murid membaca buku dia membacanya dengan hatihati, mencoba untuk membuat pemahaman dari materi itu sehingga dia dapat mengingat hampir semua hal-hal penting dan fakta yang dipelajari. Ketika murid diminta untuk menggunakan informasi tersebut untuk memecahkan masalah, ia menghasilkan banyak kemungkinan solusi. Hal tersebut terjadi karena murid tidak hanya mengingat melainkan lebih memahami dan mengerti penerapan apa yang dipelajarinya. Saat siswa membangun pengetahuan dan terjadi proses kognitif yang diperlukan untuk memecahkan masalah maka pada saat itu sedang terjadi belajar bermakna.

Anderson dan Krathwohl (2010:143) mengemukakan bagaimana guru dapat menggunakan tabel taksonomi. Pertama, Tabel taksonomi dapat membantu guru-guru lebih memahami tujuan-tujuan pembelajaran mereka (tujuan-tujuan yang mereka buat sendiri dan tujuan-tujuan yang telah disediakan oleh pihak lain); yakni, Tabel Taksonomi membantu para pendidik menjawab pertanyaan apa yang disebut dengan "pertanyaan tentang pembelajaran". Kedua, dengan pemahaman yang lebih utuh perihal tujuan-tujuan pembelajaran mereka, guru-guru dapat menggunakan Tabel Taksonomi untuk membuat keputusan-keputusan yang lebih bagus mengenai bagaimana mengajar dan mengases siswa dalam kerangka tujuan-tujuan pembelajaran itu; yakni, Tabel Taksonomi membantu para pendidik menjawab pertanyaan apa yang disebut dengan "pertanyaan tentang pembelajaran" dan "pertanyaan tentang asesmen". Ketiga, Tabel Taksonomi dapat membantu mereka menentukan seberapa sesuai antara tujuan, asesmen, dan pembelajarannya dengan cara yang tepat; yakni, Tabel Taksonomi membantu para pendidik menjawab pertanyaan apa yang disebut dengan "pertanyaan tentang kesesuaian semua komponennya." Selain menolong bagi guru yang mengajar, tabel taksonomi membantu siswa untuk memperoleh hasil belajar tidak semata pada hasil belajar mengingat dan memahami pengetahuan konseptual melainkan hingga hasil belajar mengevaluasi dan memahami pengetahuan metakognitif, mengevaluasi pengetahuan konseptual, menciptakan pengetahuan prosedural. 


\section{PENUTUP}

Taksonomi Bloom telah menjadi sebuah pemikiran yang memberi pengaruh dalam bidang pendidikan. Revisi terhadap taksonomi ini dilakukan karena kebutuhan untuk mengarahkan kembali fokus para pendidik pada Handbook dan adanya kebutuhan untuk memadukan pengetahuan-pengetahuan dan pemikiran-pemikiran baru dalam sebuah kerangka kategorisasi tujuan pendidikan. Enam kategori dalam taksonomi lama direvisi untuk menjadi lebih relevan dalam penerapannya oleh para guru. Revisi taksonomi menjadikan taksonomi Bloom menjadi lebih mudah diterapkan dan jelas dalam pemanfaatannya. Dalam revisi taksonomi perhatian lebih dalam ditujukan pada sisi pengetahuan kognitif. Taksonomi revisi melakukan perubahan dalam sub-subkategori sehingga akan lebih bermanfaat untuk merumuskan tujuan dan, dalam proses pembelajaran, untuk menstrukturkan dan mengkategorikan tujuan, aktivitas pembelajaran dan asesmen.

Belajar bermakna menolong siswa dalam proses kognitif untuk menyelesaikan masalah. Fokus belajar bermakna adalah mengkonstruksi pengetahuan sebagai usaha memahami pengalaman-pengalaman siswa. Tabel taksonomi membantu guru memahami tujuan pembelajaran, membuat keputusan yang lebih bagus mengenai bagaimana mengajar dan mengakses siswa dalam kerangka tujuan, dan membantu untuk menentukan seberapa sesuai antara tujuan, asesmen, dan pembelajaran dengan cara yang tepat.

\section{DAFTAR PUSTAKA}

Anderson, Lorin W. \& Krathwohl, David R. 2010. Kerangka Landasan Untuk Pembelajaran, Pengajaran, dan Asesmen. Yogyakarta: Pustaka Pelajar.

Darling-Hammond, Linda et al. 2003.Thinking about Thinking: Metacognition. Stanford University School of Education.

Degeng, Nyoman S. 2013. Ilmu Pembelajaran: Klasifikasi Variabel untuk Pengembangan Teori dan Penelitian. Bandung: Kalam Hidup.

Enghoff, Henrik. 2009. "What is Taxonomy", Soil Organisms, Volume 81 (3) 2009.http:// id.wikipedia.org/wiki/Taksonomi.

Huda, Miftahul. 2013. Model-model Pengajaran dan Pembelajaran. Yogyakarta: Pustaka Pelajar.

Krathwohl, David R. 2002. “A Revision of Bloom's Taxonomy: An Overview", Theory Into Practice, Volume 41, Number 4, Autum 2002. Ohio: College of Education, The Ohio State University.

Pintrich, Paul R. "The Role of Metacognitive Knowledge in Learning, Teaching, and Assessing", Theory Into Practice, Volume 41, Number 4, Autum 2002. Ohio: College of Education, The Ohio State University.

Tim Pengembang Ilmu Pendidikan UPI. 2007. Ilmu dan Aplikasi Pendidikan Bagian III: Pendidikan Disiplin Ilmu. Jakarta: Grasindo.

Turmuzi,Ahmad. 2013. Mengingat dan Memahami Kembali tentang Teori Taksonomi Bloom. Kompasiana, 5 Februari 2013, http:// edukasi.kompasiana.com 